Bidik: Jurnal Pengabdian kepada Masyarakat | Vol. 2 No. 1 Oktober 2021 Doi: https://doi.org/10.31849/bidik.v2i1.8033

\title{
Peningkatan Mutu Perpustakaan SMK Negeri 7 Pekanbaru Melalui Akreditasi
}

\author{
Rosman $\mathbf{H}^{*}$, Nining Sudiar, Hadira Latiar, \\ Prodi Ilmu Perpustakaan, Fakultas Ilmu Budaya, Universitas Lancang Kuning \\ *Email : rosman20@unilak.ac.id
}

\begin{abstract}
The school library is an institution that acts as a center for information, educational activities, research, recreation for school residents. In supporting this role, school libraries must strive to provide excellent services according to the applicable national library standards. To realize a standardired library, the school library must conduct an assessment through library accreditation. With hope, an accredited library will provide services in accordance with the needs of users. However, awareness of school library accreditation in Rian Province is still very low. This is proven by the number of accredited school libraries that have not reached 1\% of the total 1,391 school libraries in Riau Province. This has led to the holding of training and assistance related to school library accreditation for library managers or librarians of SMKN 7 Pekanbaru. The method used in this activity is to conduct training and assistance in preparing accreditation forms and preparing school library accreditation forms. The activity was delivered by means of, interactive discussion, assistance and evaluation using the checklist, pretest and posttest methods.
\end{abstract}

Keywords: accreditation, school library, pekanbaru

\begin{abstract}
Abstrak
Perpustakan sekolah merupakan sebuah institusi yang berperan sebagai pusat informasi, kegiatan pendidikan, penelitian, rekreasi bagi warga sekolah. Dalam mendukung peran tersebut, perpustakaan sekolah harus berupaya memberikan layanan yang prima sesuai standar nasional perpustakaan yang berlaku. Untuk mewujudkan perpustakaan yang berstandar, perpustakaan sekolah harus melakukan penilaian melalui akreditasi perpustakaan. Dengan harapan, perpustakaan yang sudah terakreditasi akan memberikan layanan sesuai dengan kebutuhan pemustaka. Namun kesadaran terhadap akreditasi perpustakaan sekolah di Provinsi Riau masih sangat rendah. Hal ini di buktikan dengan jumlah perpustakaan sekolah yang terakreditasi belum mencapai $1 \%$ dari total 1.391 perpustakaan sekolah di Provinsi Riau. Hal inilah yang mendorong untuk diadakannya pelatihan dan pendampingan terkait akreditasi perpustakaan sekolah kepada pengelola perpustakaan atau pustakawan sekolah SMKN 7 Pekanbaru. Metode yang dilakukan dalam kegiatan ini ialah dengan melakukan pelatihan dan pendampingan penyusunan borang dan mempersiapkan dokumen borang akreditasi perpustakaan sekolah. Kegiatan tersebut disampaikan dengan cara, diskusi interaktif, pendampingan dan evaluasi dengan metode ceklist, pretest dan posttest.
\end{abstract}

Kata kunci: akreditasi, perpustakaan sekolah, pekanbaru 


\section{Pendahuluan}

Provinsi Riau sebagai provinsi yang sedang berkembang, senantiasa memperhatikan kemajuan dari berbagai aspek, salah satumya ialah pendidikan. Salah satu unsur penting dari pendidikan adalah perpustakaan. Perpustakaan sering diibaratkan sebagai jantungnya sebuah institusi, yang menunjang kegiatan pendidikan, penelitian, kebudayaan, dan rekreasi. Salah satu indikator perpustakaan yang sesuai SNP ialah perpustakaan yang telah memperoleh pengakuan akreditasi. Tahun 2019, Provinsi Riau patut berbangga karena Perpustakaan SMK Labor Kota Pekanbaru terpilih sebagai juara 1 tingkat nasional, yang mewakili Provinsi Riau (Sindo News, 2019 ). Namun, berdasarkan rekapitulasi data dari PNRI kurang dari 1\% perpustakaan di Provinsi Riau belum terakreditasi dari 1.391 total perpustakaan sekolah di Riau. Berdasarkan aturan, sudah menjadi suatu keharusan semua perpustakaan mencapai SNP, dimana untuk mencapai SNP dibutuhkan proses penilaian yang disebut akreditasi.

SMK N Pekanbaru merupakan sekolah menengah kejuruan yang berlokasi di Kec. Rumpai Kota Pekanbaru. Sekolah tersebut telah memiliki perpustakaan yang sudah terkelola baik. Perpustakaan SMKN 7 Pekanbaru memiliki berfungsi untuk mendukung kegiatan belajar dan mengajar. Perpustakaan sebagai jantungnya lembaga pendidikan, seharusnya dikelola sesuai dengan Standar Nasional Perpustakaan (SNP) sehingga akan memperoleh pengakuan atau akreditasi. Berdasarkan pengamatan, perpustakaan yang menjadi mitra pangabdian belum memahami tentang pengisian borang akreditasi, mempersiapkan dokumen/lampiran akreditasi dan belum pernah mengajukan akreditasi perpustakaan. Sehingga mitra merasa perlu untuk melakukan akreditasi perpustakaan sebagai upaya untuk meningkatkan kualitas. Untuk mempersiapkan akreditasi, mitra melakukan kerjasama dengan akademisi untuk pembinaan dan pendampingan, dalam hal ini Prodi Ilmu Perpustakaan Fakultas Ilmu Budaya Universitas Lancang Kuning.

Sesuai Undang-undang No.43 Tahun 2007 tentang Perpustakaan bahwa semua jenis perpustakaan yang terdiri dari perpustakaan sekolah, perguruan tinggi, khusus, dan umum harus sesuai dengan Standar Nasional Perpustakaan (Perpustakaan Nasional RI, 2008). Untuk mencapai SNP ini dibutuhkan proses penilaian yang dinamakan akreditasi. Berdasarkan data sensus PNRI 2018, dari 164.000 perpustakaan berbagai jenis yang ada di Indonesia dan sudah sesuai dengan SNP masih sangat kecil (Perpustakaan Nasional RI, [2018]).

Pentingnya perpustakaan mendapatkan akreditasi adalah menunjukkan perpustakaan sudah memenuhi standar sesuai regulasi yang ada dan tentu saja kepuasan pemakai akan terwujud ketika perpustakaan sudah memenuhi instrument SNP. Selanjutnya imbas dari perpustakaan yang memenuhi standar akan memberikan pelayanan prima, peningkatan budaya gemar membaca, meningkatkan peran perpustakaan dalam mencerdaskan kehidupan, serta memberikan sumbangan skor ketika sekolah akan melakukan akreditasi institusi.

Berdasarkan hasil identifikasi pada mitra, maka diketahui permasalahan yang dihadapi, yaitu terbatasnya pengetahuan pustakawan terkait pengisian borang akreditasi perpustakaan sekolah untuk mencapai Standar Nasional Perpustakaan (SNP), mempersiapkan dokumen/lampiran borang serta mekanisme pengajuan akreditasi perpustakaan sekolah sehingga pustakawan perlu untuk mendapatkan pendampingan dan pembinaan dalam bentuk pelatihan dan pendampingan terkait pengisian borang, penyiapan dokumen/laporan borang akreditasi, dan pengiriman borang akreditasi. 


\section{Pedekatan Pelaksanaan Program}

Kegiatan pengabdian ini diperuntukkan pustakawan sekolah yang menjadi mitra pengabdian. Pelaksanaan kegiatan pengabdian masyarakat ini dikemas menggunakan pendekatan sosialisasi SNP dan akreditasi, workshop pengelolaan perpustakaan sekolah dan bimtek penyusunan borang akresitasi. Kegiatan tersebut disampaikan menggunakan metode ceramah, diskusi interaktif dan praktek. Jumlah peserta yang terlibat dalam kegiatan ini sekitar 3 orang yang terdiri dari kepala sekolah, staf perpustakaan dan pustakawan. Agar pelaksanaan kegiatan berjalan dengan lancar sesuai dengan tujuannya, maka dilakukan langkah-langkah sebagai berikut:

Pertama, melakukan evaluasi pre-test kepada seluruh peserta sebelum pelatihan dimulai. Pada tahap pertama, peserta diberikan 5 (lima) pertanyaan pre-test dengan jawaban pilihan ganda yang dibagikan kepada peserta yang datang.

Kedua, memberikan materi pokok kepada peserta, pada tahap ini, peserta pelatihan diberikan materi mengenai pentingnya akreditas perpustakaan sekolah, Standar Nasional Perpustakaan (SNP), dan instrument akreditasi perpustakaan sekolah. Hal ini penting dilakukan untuk menyamakan persepsi materi yang akan disampaikan, materi yang disampaikan pada tahap ini adalah:

a. Undang-undang Republik Indonesia No.43 Tahun 2007 tentang Perpustakaan

b. Manajemen Perpustakaan Sekolah (Hartono, 2017)

c. Standar Nasional Perpustakaan (SNP) (Perpustakaan Nasional RI, 2018)

Peralatan yang dibutuhkan:

a. Proyektor

b. Laptop

c. Handout materi

d. Power Point

e. Handout instrument akreditasi perpustakaan sekolah menengah atas/madrasah (PNRI, 2018)

Ketiga, diskusi interkatif, peserta diberikan kesempatan untuk mendiskusikan materi yang telah disampaikan. Kesempatan tanya-jawab diberikan oleh narasumber bertujuan untuk memperjelas hal-hal yang perlu diuraikan, sehingga tidak terjadi keraguan.

Keempat, praktik simulasi penyusunan borang akreditasi. Pada tahap ini, tim pelaksana bersama dengan peserta melakukan praktik simulasi penyusunan borang akreditasi sesuai instrument akreditasi perpustakaan sekolah. Materi yang disampaikan:

a. Instrumen Akreditasi Perpustakaan Sekolah

b. Praktik penyusunan artikel ilmiah

Peralatan yang dibutuhkan:

a. Laptop

b. Power Point

c. Proyektor

d. Praktek penyusunan borang akreditasi perpustakaan sekolah

Tahap ini peserta diberikan bimbingan penyusunan borang akreditasi perpustakaan sekolah, luaran yang diharapkan yaitu draf kasar borang akreditasi. Selanjutnya Hasil penyusunan borang 
tersebut dikumpulkan dan dianalisis oleh tim dan narasumber untuk dianalisis dan diberikan masukan untuk perbaikan lebih lanjut oleh tim.

Kelima, melakukan evaluasi akhir dari kegiatan bimtek melalui post-test kepada seluruh peserta setelah selesai kegiatan, peserta dipersilahkan mengisi 5 (lima) soal pilihan ganda. Hasil post-test ini akan dianalisis oleh tim untuk melihat tingkat pemahaman peserta terhadap materi yang telah diberikan oleh narasumber.

\section{Pelaksanaan Program}

Kegiatan pengabdian kepada masyarakat dilaksanakan dalam bentuk pendampingan dalam rangka mempersiapkan akreditasi perpustakaan SMK Negeri 7 Pekanbaru telah selesai dilaksanakan pada bulan Februari sampai Juni 2020. Kegiatan tersebut terlaksana dengan baik. Mitra dalam kegiatan ini adalah Perpustakaan SMK Negeri 7 Pekanbaru yang terdiri dari kepala perpustakaan, pustakawan dan staf perpustakaan. Kegiatan dilaksanakan di ruang perpustakaan SMK Negeri 7 Pekanbaru yang berlokasi di Jalan Yos Sudarso Km. Rumbai Pesisir Pekanbaru.

Sebelum melaksanakan kegiatan, tim melakukan analisis situasi dan kebutuhan di lapangan. Kegiatan ini dilakukan dengan berdiskusi dengan Mitra dan survey singkat di lapangan terkait kemampuan pustakawan dalam mengisi borang akreditasi perpustakaan sekolah dasar. Setelah tim melakukan analisis situasi dan permasalahan mitra, masing-masing mitra menyambut baik yang akan dilaksanakan, yakni pendampingan pengisian boring akreditasi. Bentuk partisipasi mitra ditunjukkan dengan kesediaannya untuk menyiapkan tempat, mempersiapkan perlengkapan, dan menjadi penanggung jawab kegiatan sehingga kegiatan berlangsung dengan baik. Antusiasme dan semangat mitra sangat tinggi dapat dilihat pada gambar 1 berikut.

Gambar 1. Pendampingan Pengisian Borang Akreditasi Perpustakaan
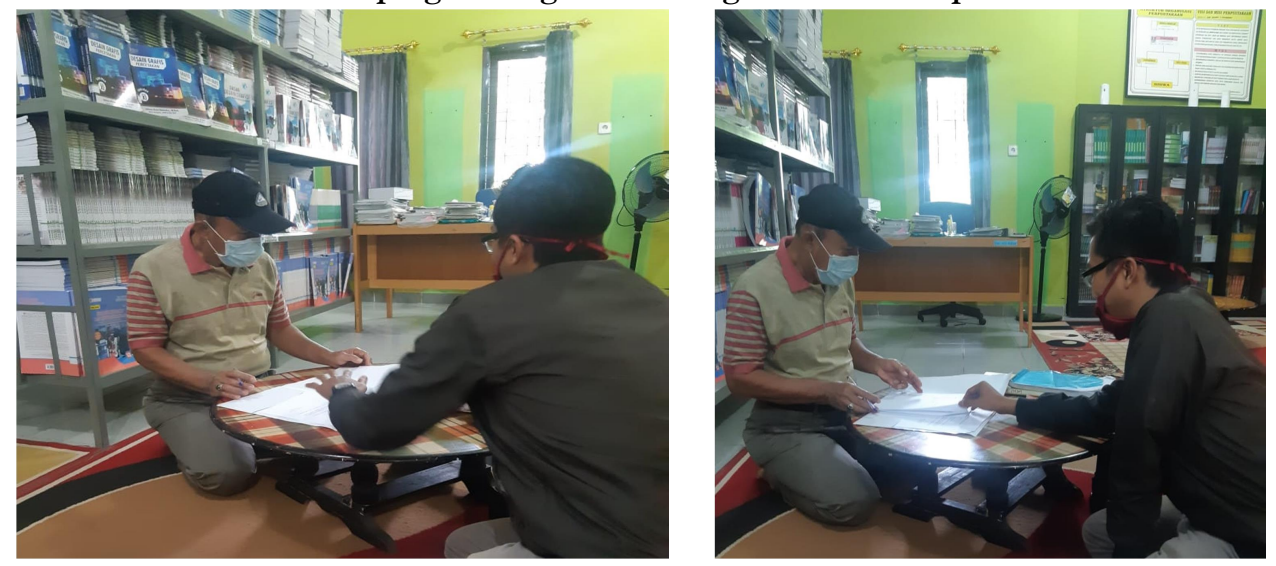

Selama kegiatan pendampingan, beragam pertanyaan diajukan kepada tim pendamping. Tampak mitra memiliki keinginan untuk meningkatkan mutu perpustakaan melalui akreditasi. Mereka sadar bahwa perpustakaan memiliki posisi strategis dalam mendukung kegiatan belajar mengajar di sekolah. Hal ini karena perpustakaan merupakan jantungnya sebuah institusi pendidikan yang menunjang proses kegiatan belajar mengajar bagi tenaga pendidik, tenaga kependidikan dan siswa maupun masyarakat sekitar. 
Materi yang disampaikan oleh tim kepada mitra adalah tentang akreditasi perpustakaan, pengisian borang akreditasi perpustakaan. Dalam pelaksanaannya, materi diberikan dalam beberapa bagian, yaitu; pertama, diberikan materi tentang akreditasi perpustakaan, kedua tentang teknik pengisian borang akreditasi, dan ketiga peserta diberikan tips dan trik dalam kegiatan akreditasi perpustakaan sekolah. Tahap pelaksanaan kegiatan workshop dilakukan dengan beberapa tahapan.

1. Mempersiapkan data kuantitaif

Mitra mempersiapkan data-data kuantitatif terkait pengisian borang akreditasi perpustakaan. Pada tahap ini peserta mempersiapkan data perpustakaan seperti jumlah koleksi, data sarana prasarana, data kegiatan-kegiatan yang dilaksanakan perpustakaan, sumberdaya manusia dan lain-lain yang dianggap perlu untuk mendukung kegiatan pengisian borang akreditasi perpustakaan sekolah.

2. Materi tentang pengisian borang akreditasi perpustakaan

Tim memberikan materi tentang pengisian borang akreditasi perpsutakaan sekolah. Tahap ini peserta diberikan kesempatan untuk berdiskusi untuk menyamakan persepsi tentang pengisian borang akreditasi.

3. Pengisian Borang Akreditasi

Tim membagikan borang akreditasi mitra. Selanjutnya mitra mengisi borang akreditasi yang telah dibagikan yang dibimbing oleh tim pendamping.

4. Mengoreksi hasil pengisian borang akreditasi

Tim mengoreksi borang akreditasi yang telah diisi oleh mitra. Kegiatan ini bertujuan untuk melihat skor yang diperoleh dari borang yang telah diisi. Dalam tahap ini borang akreditasi Perpustakaan SMK Negeri 7 Pekanbaru memperoleh skor 79,25 dapat dikategorikan bahwa perpustakaan SMK Negeri Pekanbaru Terkareditasi B.

Hasil dari kegiatan ini adalah berupa peningkatan pemahaman dan kemampuan mitra dalam memahami materi yang disampaikan. Hal tersebut ditunjukkan dengan kemampuan mitra dalam mengisi borang akreditasi perpustakaan sekolah. Selain itu, hasil evaluasi dari kuesioner pretest dan posttest diperoleh hasil bahwa peserta mengalami peningkatan pemahaman dan kemampuan dalam mengisi borang akreditasi perpustakaan. Hasil tersebut dapat dilihat pada tabel 1 berikut.

Tabel 1. Hasil Pretest dan Postest

\begin{tabular}{|l|l|c|c|c|}
\hline No & \multicolumn{1}{|c|}{ Materi } & Pretest (\%) & $\begin{array}{c}\text { Post test } \\
\text { (\%) }\end{array}$ & Peningkatan (\%) \\
\hline 1. & $\begin{array}{l}\text { Pemahaman konsep akreditasi } \\
\text { perpustakaan }\end{array}$ & 57,75 & 88,50 & 30,75 \\
\hline 2. & $\begin{array}{l}\text { Kemampuan pengisian borang } \\
\text { akreditasi }\end{array}$ & 45,03 & 85,67 & 40,64 \\
\hline
\end{tabular}

Data diolah Juni 2020 
Tabel 3 menunjukkan bahwa seluruh materi yang disampaikan tim dapat dipahami dengan baik oleh peserta. Pada indikator pemahaman tentang konsep akrediasi perpustakaan SD/MI mengalami peningkatan sebesar 30,75\%. Sedangkan pada indikator kemampuan pengisian borang akreditasi mengalami peningkatan sebesar 40,64\%. Berdasarkan hasil tersebut tim berkesimpulan bahwa peningkatan pemahaman dan kemampuan tersebut karena antusiasme peserta dan keinginan peserta untuk meningkatkan mutu perpustakaan melalui akreditasi perpustakaan sekolah.

Berdasarkan hasil evaluasi, ditemukan beberapa hal yang menjadi rekomendasi untuk kegiatan yang akan datang. Temuan tersebut antara lain, persiapan data-data peserta workshop yang kurang lengkap, seperti belum memiliki Nomor Pokok Perpustakaan (NPP), laporan-laporan kegiatan, dan lain sebagainya.

\section{Refleksi Capaian Program}

Kesimpulan dari hasil pemaparan kegiatan yang telah dilaksanakan bahwa secara umum seluruh target yang direncanakan telah tercapai dengan baik dan sesuai dengan usulan program Pengabdian kepada Masyarakat. Kegiatan ini mendapat respon positif dari para pesera yang dapat dilihat dari jumlah peserta yang dating, serta antusiasme peserta selama workshop berlangsung. Selanjutnya terjadi peningkatan pemahaman dan kemampuan peserta dalam mengisi borang akreditasi. Indikator tersebut ditunjukkan dari hasil evaluasi pretest dan post test yang terjadi peningkatan yang cukup signifikan. Sementara luaran utama dari kegiatan ini berupa artikel ilmiah yang berhasil dikirim ke jurnal Dinamisia LPPM Universitas Lancang Kuning.

\section{Penutup}

Beberapa rekomendasi yang tim berikan terkait hasil kegiatan yang telah dilaksanakan antara lain:

1. Dari kegiatan yang telah dilaksanakan sebaiknya menjadi pedoman dan dilaksanakan oleh pustakawan sekolah dalam mempersiapkan akreditasi perpustakaan sekolah.

2. Berdasarkan pengamatan tim, kagiatan serupa perlu dilaksanakan workshop serupa guna memberikan pendampingan dan bimbingan dalam proses kegiatan akreditasi perpustakaan.

\section{Daftar Pustaka}

Hartono. (2017). Manajemen Perpustakaan Sekolah: Menuju Perpustakaan Modern dan Profesional. Jakarta: Ar-Ruzz Media.

Perpustakaan Nasional RI. ([2018]). Pendataan Perpustakaan. Retrieved Agustus 29, 2019, from Pendataan Perpustakaan Berbasis Wilayah: http://data.perpusnas.go.id/?r=laporan/jumlahperpustakaan

Perpustakaan Nasional RI. (2008). Undang-Undang Nomor 43 Tabun 2007 tentang Perpustakaan. Jakarta: Perpustakaan Nasional RI.

Perpustakaan Nasional RI. (2018, Mei 20). Perpustakaan Nasional RI: Standar Nasional Perpustakaan (SNP). Retrieved Agustus 29, 2019, from Perpustakaan Nasional RI: http://old.perpusnas.go.id/Attachment/Pedoman/standar\%20nasional\%20perpustakaansekolah.pdf 
PNRI. (2018, Juli 5). perpusnas.go.id. Retrieved Oktober 20, 2019, from www.perpusnas.go.id/: www.perpusnas.go.id/instrumen_akreditasi_perpustakaan_sekolah_menegah_atas_\%.

Sindo News. (2019, Agustus 19). Pustaka SMK Labor Pekanbaru Juara I Lomba

Perpustakaan Tingkat Nasional. Retrieved Agustus 29, 2019, from Sindo News: https://daerah.sindonews.com/read/1431353/174/pustaka-smk-labor-pekanbaru-juara-ilomba-perpustakaan-tingkat-nasional-1566205250. 